\title{
A Review of the Seeds Comprising Panch phoron, a Spice used in Indian Cuisine
}

\author{
Debjani Sarkar* \\ Department of Zoology, Acharya Prafulla Chandra Roy Government College, Darjeeling, West Bengal, INDIA.
}

\begin{abstract}
India houses a wide variety of plants with medicinal properties on account of being a megadiversity country. Spices, comprising different parts of a plant (seeds, bark, etc.), are substances used for adding flavor to and preserving food items. They possess a myriad of health benefits, uses of which are documented in ancient literature. Panch phoron is a mixture of five spices, comprising whole seeds of cumin, fennel, fenugreek, mustard and black cumin. It is widely used in India, especially Eastern India, for adding flavor to food in daily cooking. The present study delves into various pharmacological properties of each of the five seeds comprising panch phoron and is necessitated by the current interest in plant products as a cheaper and far better alternative than the synthetic drugs available but associated with side effects. It was seen that the seeds have myriad properties such as antimicrobial, antioxidant, antitumorigenic, anti-inflammatory, antidiabetic, gastroprotective and cardioprotective and may be
\end{abstract}

used for the treatment of diabetes, cancer, inflammation, kidney problems, liver problems, etc., following proper scientific validation and long-term trials. The review aspires to scientifically validate the vast traditional use of this spice in the Eastern Indian cuisine and its immense scope in herbal therapeutics in the future.

Key words: Black cumin, Cumin, Fennel, Fenugreek, Mustard, Panch phoron.

\section{Correspondence}

Dr. Debjani Sarkar,

Department of Zoology, Acharya Prafulla Chandra Roy Government College, Darjeeling-734010, West Bengal, INDIA.

Phone no: (+91) 9433470817

Email: debjani_sarkar2002@yahoo.co.in

DOI: 10.5330/ijpi.2019.2.7

\section{INTRODUCTION}

Almost all over the world today, plant products are increasingly gaining precedence over synthetic drugs by virtue of their fewer side effects and far greater affordability. ${ }^{1}$ The World Health Organization states that a majority of the world's population, particularly in developing countries, depends on herbal remedies or traditional medicine for their primary health care and treatment and has encouraged them to use the plants as a resource to generate effective health care. ${ }^{2}$ In such a scenario, it is obvious that a megadiversity country like India, which is a veritable treasure trove of plants rich in medicinal and curative properties, will hold a status of immense significance. This is where exhaustive treasure of spices factors in as one of the major determinants for India's growing prominence.

Spices (seed, root, fruit, bark, or any other part of the plant) are aromatic substances used for seasoning or adding flavor to or preserving food items. They have been an integral part of both Indian cuisine and Indian culture since time immemorial. Spices have been conventionally used as household remedies for minor external injuries or internal discomfort. They have found place in Ayurveda for their medicinal properties.

"Panch phoron," a mixture of five spices, is widely used especially in Eastern India, to add flavor to food. It is a whole spice blend of cumin, fennel, fenugreek, mustard and black cumin seeds obtained from Cuminum cyminum, Foeniculum vulgare, Trigonella foenum-graecum, Brassica juncea (and other species) and Nigella sativa plants, respectively. ${ }^{3}$ The present review aspires to collate the information available on the medicinal properties of the seeds of the plants named above and bridge the gap between the conventional use and the scientific validation of the same.

\section{METHODS}

The names of the constituents were collected from the elderly women of the household and matched with information available on online database. The five constituents were then separately explored for their respective properties (citing the constituent and mentioning a specific property) across PubMed, Google, ScienceDirect, etc. The information accumulated for each of the constituents was then separated on the basis of their properties.

\section{Panch phoron: The manifold significance}

The use of Panch phoron is prevalent as an integral element in cooking in various parts of India (mainly Bengal, Bihar, Assam and Orissa) and Nepal (where it is called padkaune masala). Although quite extensively used in Assam and Orissa as pas phoron and pancha phutana, respectively, panch phoron, i.e., variety in extensive use across Bengal, is the most well-known form of the usage of the five spices in Indian cooking. ${ }^{[4]}$ "Phoron" in Bengali means tempering, an indispensable part of Eastern Indian cuisine, deriving from the Sanskrit word, "photon" meaning explosion.

The idea behind the usage of five spices in India is not limited to gastronomical pleasures only but is endowed with religious and spiritual dimensions as well. The number five conforms to the auspicious power of five, as evident in the concepts of the Pancha bhoota or the five elements of earth, air, sky, water and fire; Panchendriya or the five sense organs: eye, ear, nose, tongue and skin; Panchamrita or the perfectly blended offering of milk, yogurt, honey, ghee and sugar in Hindu religious rituals. In "Haramangal," one of the Mangalkavyas, cultivation of Pancha shashya or the five crops - rice, sesame, barley, mustard and corn-is highlighted. Moreover, the number five is accorded another intriguing dimension as part and parcel of Bengali day-to-day cuisine in the form of pancha byanjon (five dishes) and panchmeshali (a mix of five vegetables) or Panch phoron. ${ }^{5}$ 
It would, however, be wrong to infer that the Panch phoron concept is an intransigently Hindu idea. The idea of five includes a Buddhist dimension as well, corresponding to the significance ascribed to the five senses, five colors, etc. Moreover, the concept of five marks the convergence of the Buddhist and Hindu traditions as both of these traditions hold that food should be cooked by following the five prime techniques of boiling, steaming, frying, roasting, or grilling and stewing and thereafter enjoyed with all the five senses. ${ }^{5}$ The Panch phoron concept is celebrated in the blend of five flavors - salt, sweet, sour, bitter and pungent.

\section{Panch phoron: The constituents}

All the five components of Panch phoron are whole seeds obtained from vascular plants belonging to Kingdom Plantae; Subkingdom: Tracheobionta; Superdivision: Spermatophyta; Division: Magnoliophyta and Class: Magnoliopsida. All of them are obtained from dicotyledonous

Table 1: Scientific names and systematic position of plants from which Panch phoron is obtained.

\begin{tabular}{|c|c|c|c|}
\hline $\begin{array}{c}\text { Common name of the } \\
\text { constituent (colloquial } \\
\text { name) }\end{array}$ & $\begin{array}{c}\text { Scientific } \\
\text { name of the } \\
\text { plant }\end{array}$ & $\begin{array}{c}\text { Systematic position } \\
\text { (subclass/order/ } \\
\text { family) }\end{array}$ & $\begin{array}{l}\text { Plant } \\
\text { part } \\
\text { used }\end{array}$ \\
\hline Cumin (jeera) & $\begin{array}{l}\text { Cuminum } \\
\text { cyminum }\end{array}$ & $\begin{array}{l}\text { Subclass: Rosidae } \\
\text { Order: Apiales } \\
\text { Family: Apiaceae }\end{array}$ & Seed \\
\hline Fennel (mauri/saunf) & $\begin{array}{c}\text { Foeniculum } \\
\text { vulgare }\end{array}$ & $\begin{array}{l}\text { Subclass: Rosidae } \\
\text { Order: Apiales } \\
\text { Family: Apiaceae }\end{array}$ & Seed \\
\hline Fenugreek (methi) & $\begin{array}{l}\text { Trigonella } \\
\text { foenum- } \\
\text { graecum }\end{array}$ & $\begin{array}{l}\text { Subclass: Rosidae } \\
\text { Order: Fabales } \\
\text { Family: Fabaceae/ } \\
\text { leguminosae }\end{array}$ & Seed \\
\hline Mustard (sarson/rai) & $\begin{array}{l}\text { Brassica } \\
\text { juncea }\end{array}$ & $\begin{array}{l}\text { Subclass: Dilleniidae } \\
\text { Order: Capparales } \\
\text { Family: Brassicaecae/ } \\
\text { Cruciferae }\end{array}$ & Seed \\
\hline $\begin{array}{l}\text { Black cumin (kalonji/ } \\
\text { kalojeera) }\end{array}$ & Nigella sativa & $\begin{array}{l}\text { Subclass: Magnoliidae } \\
\text { Order: Ranunculales } \\
\text { Family: Ranunculaceae }\end{array}$ & Seed \\
\hline
\end{tabular}

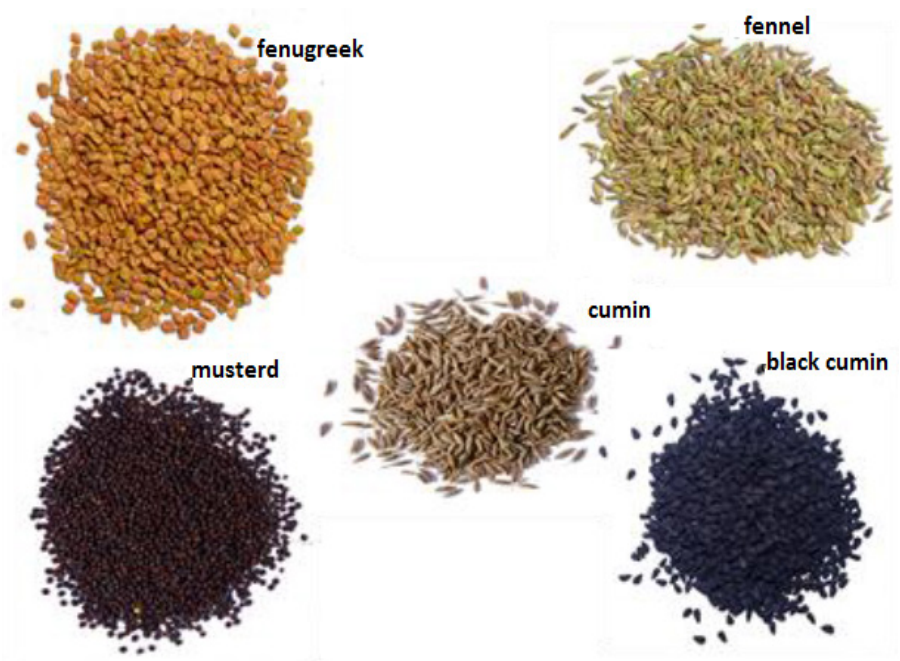

Figure 1: The seeds comprising panch phoron. Panch phoron is composed of whole seeds obtained of cumin, fennel, fenugreek, mustard and black cumin as shown. plants belonging to different orders and families [Table 1]. The morphology of seeds [Figure 1] and their traditional use have been described as follows:

\section{Cumin}

Cumin, better known as jeera, belongs to the Umbelliferae (Apiaceae) family and provides us with $36 \mathrm{~mm}$-long seeds that come as paired or separate carpels and are hairy, brownish, concave and acuminate at each extremity with tiny stalks attached. The oil of cumin is used as a seasoning in curry powders, soups, stews, meats and chutneys. ${ }^{6}$ In traditional medicine, cumin was used to treat hoarseness, jaundice, dyspepsia and diarrhea. Its seeds were used for stomachic, diuretic, carminative, stimulant, astringent and abortifacient properties. ${ }^{7,8}$ In India, cumin was used as an abortifacient, for kidney and bladder stones, chronic diarrhea, leprosy and ocular disease. ${ }^{9}$ In Unani system of medicine, the fruits of Cuminum cyminum were used as an astringent and carminative, for the treatment of corneal opacities, ulcers and boils, to relieve cough and inflammation. ${ }^{10}$ In Iranian traditional medicine, cumin seeds were used for the treatment of toothache, diarrhea, epilepsy, as well as gastrointestinal and respiratory disorders. ${ }^{11}$

\section{Fennel}

More popular as mauri or saunf, fennel is an ancient seasonal herb that holds from the same Umbelliferae (Apiaceae) family as of cumin. Seeds are elliptical, slightly curved and somewhat obtuse at the ends. The herb was well known to the ancient Egyptians, Romans, Indians and Chinese. It is an indispensable ingredient in modern French and Italian cooking. Fennel is used in various traditional systems of medicine such as in the Ayurveda, Unani and Siddha in the Indian and Iranian traditional systems of alternative and balancing medicine. ${ }^{12}$ Its stem, fruit, leaves, seeds and whole plant itself are medicinally used in different forms in the treatment of a variety of diseased conditions. From ancient times, fennel seeds have been used as an ingredient for removing any foul smell of the mouth. ${ }^{13}$ Sugar coated and uncoated fennel seeds are used in mukhwas (mouth freshener), a colorful after meal mouth freshener or digestive aid. ${ }^{14}$

\section{Fenugreek}

Famous as methi, fenugreek is one of the earliest spices known to humanity to be used as preservatives to pickles. Fenugreek comes from the Fabaceae (Leguminosae) family and yields seeds that are rich in Vitamin E, pleasantly bitter in taste with a slightly sweet savor. Fenugreek seed has a central hard and yellow embryo which is surrounded by a corneous and comparatively large layer of white and semi-transparent endosperm. ${ }^{15}$ Seeds of fenugreek spice have medicinal properties such as hypocholesterolemic, lactation aid, antibacterial and gastric stimulant, for anorexia, antidiabetic agent, hepatoprotective and anticancer agent. ${ }^{16}$ In ancient Egypt, methi was used to ease childbirth, to increase milk flow and modern Egyptian women are still using it today to relieve menstrual cramps. ${ }^{17}$ Traditional Chinese herbalists used it for kidney problems and conditions affecting the male reproductive tract. Fenugreek seeds reduce the amounts of calcium oxalate in the kidneys, which often contributes to kidney stones. In animal studies, fenugreek appeared to lessen the chance of developing colon cancer by blocking the action of certain enzymes. ${ }^{17}$

\section{Mustard}

Mustard or Brassica, better known as sarson or rai, belongs to the Brassicaceae family and is one of the most ancient spices. It has three varieties, namely black, brown and white. The variously shaped seeds are usually yellow or brown and arranged in one or two rows in each 
cavity. The seed leaves are entire or have a notch at the tip. ${ }^{[18]}$ Brown mustard (B. juncea) plant produces tiny yellow flowers. Mustard seed has a fresh aroma and slightly biting flavor. ${ }^{19}$ Seed oil is used for cooking purpose. Mustard is used in Indian, French, German and Irish cuisines. Mustard is used in salad dressings, added to meat, egg and vegetables to impart a unique taste to the dish. It is also a folk remedy for arthritis, foot ache and rheumatism. ${ }^{20}$ It has emetic, digestant, antiinflammatory and irritant properties. It is used to treat abdominal pain, anorexia, worms and diseases of the spleen, tumors and wounds. ${ }^{21}$ Seeds are used for curing tumors in China. In Korea, the seeds are used for abscesses, colds, rheumatism, lumbago and stomach disorders. Mustard oil is used for skin eruptions and ulcers. ${ }^{22}$ Massaging the body with mustard oil is very beneficial as it is thought to improve blood circulation, muscular development and to give a good texture to human skin. The oil is also antibacterial. In skin diseases, the local application of seed oil is beneficial as it is antiseptic and anti-inflammatory. The oil, with salt, is an effective gargle in dental infections and pyorrhea. ${ }^{23}$

\section{Black cumin}

N. sativa belongs to family Ranunculaceae and has a rich historical and religious background. It is very popular in various traditional systems of medicine like Ayurveda. In Islamic literature, it is believed to prevent every disease except death. ${ }^{24}$ The seeds are dicotyledonous with a black exterior and white interior. ${ }^{25}$ It has a slight aromatic odor and bitter in taste. The seeds were used as appetizer, stimulant and sedative. ${ }^{25,26}$ In traditional Arabic herbal medicine, black cumin is used to treat a plethora of diseases such as skin diseases, jaundice, rheumatism, diabetes, hypertension, paralysis, amenorrhea, anorexia, asthma, cough and eczema. ${ }^{25,26}$

\section{Properties of the seeds present in "Panch phoron" Microbicidal properties}

Four (cumin, fennel, fenugreek and black cumin) among the five seeds have been reported to have antimicrobial properties. Cumin and fennel inhibited the growth of several Gram-positive and Gram-negative bacterial species such as Escherichia coli, Salmonella typhi, Pseudomonas aeruginosa, Klebsiella pneumonia and Staphylococcus aureus just to name a few. ${ }^{27-29}$ Some studies claim that essential oil of cumin and aqueous extract of fennel were ineffective against $P$. aeruginosa and $K$. pneumonia. ${ }^{29-31}$ The seed extracts of fenugreek (aqueous and methanolic) were found more effective against E. coli, S. typhi, S. aureus and several other species. ${ }^{17,32}$ Nigella seeds were the most studied for their antimicrobial activity and were found to be effective against 16 Gram-negative and 6 Gram-positive bacterial strains. ${ }^{[33]}$ In most of the above cases, the antibacterial activity was studied using the agar diffusion method. Cuminaldehyde and thymoquinone obtained from cumin and black cumin, respectively, were mainly responsible for their antibacterial activity. ${ }^{31,34}$ The antibacterial activity of Brassica nigra had been studied, but very few reports of the antibacterial activity of $B$. juncea have been found. ${ }^{35}$ Khan et al. have shown that brown mustard inhibits growth of Bacillus subtilis, E. coli and Rhodococcus. ${ }^{36}$ Allyl isothiocyanate (AITC) obtained from plants of Brassicaceae family inhibited E. coli growth, but the study has not been done in Indian mustard. ${ }^{37}$

All the four seeds stated above have potent antifungal properties. Essential oil from cumin showed high activity against Candida albicans, Aspergillus niger, Botrytis cinerea, Rhizopus stolonifer and Saccharomyces cerevisiae. ${ }^{31,38}$ Both cumin and fennel essential oils were effective against A. niger, $R$. stolonifer and B. cinerea; cumin oil being more effective; however, $A$ niger was completely inhibited by fennel. ${ }^{38}$ Essential oil and alcoholic and aqueous extract of fennel seeds were effective against a variety of fungi namely C. albicans, Aspergillus flavus, Alternaria alternata,
Fusarium oxysporum, Rhizoctonia solani, A. niger, Fusarium solani, Rhizopus solani and Mucor rouxii. ${ }^{39,40}$ The aqueous extract was effective against Alternaria sp., while the ethanolic extract was effective against Mucor sp. ${ }^{40}$ Haouala et al. 2008 have reported the activity of fenugreek seeds against Botrytis cinerea, Fusarium graminearum, Alternaria sp., Pythium aphanidermatum and R. solani. ${ }^{41}$ Seeds that were not grounded showed a better activity than grounded ones. ${ }^{41}$ Many other researchers have reported the activity of water and petroleum ether extract against several other species of fungi such as Candida sp. and Aspergillus sp. ${ }^{32,42}$ The methanolic extract of $N$. sativa seeds followed by the chloroform extract showed potent antifungal activity against Candida sp., while aqueous extract of the same is doubtful as a group of researchers claim otherwise. ${ }^{43}$ Two antifungal defensins isolated from seeds displayed strong activity against various fungi. ${ }^{44}$ Brown mustard was also reported to have antifungal activity against Helminthosporium maydis, Conophytum truncatum, Mycosphaerella arachidicola, Ascochyta rabiei, etc. AITC, juncin and chitinase BjCHI1 isolated from the seeds were held responsible for its antifungal activity. ${ }^{45,46}$

Thymoquinone obtained from $N$. sativa has antiprotozoal activity as evidenced by their killing of Entamoeba histolytica, Giardia lamblia and Schistosoma mansoni. ${ }^{47,48}$ Antihelminthic properties of fenugreek has not been reported on any human helminth parasite but on Gastrothylax crumenifer in cattle and on Pheretima. ${ }^{49}$ Antihelminthic activity of the hydroalcoholic extract of mustard seeds was proved by experiments on earthworm. ${ }^{50}$

\section{Antioxidant activity}

All the seeds show antioxidant activity and inhibited production of free radicals. Cumin, fenugreek and Nigella seeds inhibited lipid peroxidation and increased protein and nonprotein antioxidant enzymes such as catalase, superoxide dismutase (SOD) and glutathione (GSH). ${ }^{7}$ The protective effect of polyphenol-rich extract from the seeds of fenugreek gave protection against hydrogen peroxide $\left(\mathrm{H}_{2} \mathrm{O}_{2}\right)$-induced oxidation in normal and diabetic human erythrocytes (RBCs). ${ }^{17}$ The extracts of endosperm husk and fenugreek seed at about $200 \mu \mathrm{g}$ concentration exhibited antioxidant activity of $72 \%, 64 \%$ and $56 \%$, respectively, by free-radical scavenging method. ${ }^{51}$ Bukhari et al. reported that fenugreek seed extract with methanol, ethanol, dichloromethane, acetone, hexane and ethyl acetate has a radical scavenging activity. ${ }^{52}$ Fenugreek also increased 1,2-dimethylhydrazine-induced reduction in GSH, glutathione S-transferase, catalase and SOD activity. ${ }^{53}$

Fully ripened seeds of cumin exhibited higher antioxidant activity than the unripe ones which may be due to higher quantity of polyphenols and condensed tannin. ${ }^{54}$ Cumin also increased the decreased levels of antioxidant enzymes in diabetic rats. ${ }^{55}$ The presence of monoterpene alcohols is responsible for the antioxidant activity of cumin oils. ${ }^{56}$

Fennel seed extract (water and methanol) scavenged free radicals such as $\mathrm{H}_{2} \mathrm{O}_{2}$ and superoxide anion, have reducing power and has iron chelating activity. ${ }^{57}$ Fennel increases GSH levels and catalase activity induced by oxidative stress and cancer. ${ }^{58,59}$ Treatment of obese women with fennel supplement increased SOD and GSH levels in the subjects. ${ }^{60}$

Thymoquinone obtained from black cumin seeds inhibited oxidative stress, reduced lipid peroxidation and increased the activities of enzymes such as glutathione S-transferase, myeloperoxidase and catalase. ${ }^{61,62}$

Mustard seeds are also claimed to have antioxidant properties, but most of the studies had been done in other species of Brassica and detailed study is yet to be done. A few studies have shown that mustard seeds prevented free radical scavenging, metal chelation and protected DNA against oxidative damage. . $3364^{2}$ 


\section{Anti-inflammatory and analgesic activity}

Cumin, fenugreek and black cumin have both anti-inflammatory and analgesic properties. Cumin inhibited carrageenan-induced paw edema and cotton pellet-induced granuloma to display its anti-inflammatory property in vivo. ${ }^{65}$ The anti-inflammatory property was exhibited by the upregulation of anti-inflammatory mediators and downregulation of pro-inflammatory mediators. Cumin essential oil inhibited mRNA expressions of inducible nitric oxide (NO) synthase, cyclooxygenase-2 (COX-2), interleukin-1 (IL-1) and IL-6 in lipopolysaccharide-(LPS-) stimulated RAW 264.7 cells. $^{66} \mathrm{~N}$. sativa inhibited proinflammatory cytokines such as IL-1 and IL- $6 .{ }^{67}$ Thymoquinone obtained from $N$. sativa reduced proinflammatory mediators such as NO, IL-1 $\beta$, IL-6, tumor necrosis factor (TNF)- $\alpha$, interferon- $\gamma$, COX-2 prostaglandin and increased IL-10 response in both in vitro and in vivo studies. ${ }^{68}$ Both cumin and black cumin inhibited the signaling pathways to display their anti-inflammatory properties. Cumin essential oil blocked LPS-induced nuclear factor-kappa B (NF- $\kappa \mathrm{B})$, c-Jun N-terminal kinase and extracellular signal regulated kinase (ERK) pathway. ${ }^{66}$ N. sativa inhibited transcription factor NF- $\kappa \mathrm{B} .{ }^{67}$

Fenugreek seeds inhibited carrageenan- and formaldehyde-induced paw edema, cotton pellet-induced granuloma and Freund's adjuvant-induced arthritis. ${ }^{69}$ Fenugreek also possessed analgesic activities as proven by chemically induced writhing method and hot plate method. ${ }^{70}$ It also inhibited proinflammatory mediators such as IL-1 $\beta$, IL-6, TNF- $\alpha$, IL-8 and NF- $\kappa \mathrm{B}$ signaling activity. ${ }^{71}$ Trigonelline from fenugreek downregulated LPS induced TNF- $\alpha$, NF- $\kappa B$ and Toll-like receptor- 4 activity, but only a few reports on the anti-inflammatory activity of trigonelline isolated from fenugreek are found. ${ }^{72}$

In case of the anti-inflammatory activity of fennel, far fewer studies than fenugreek exist. It inhibited intestinal inflammation by inhibiting $\mathrm{NF}-\kappa^{73}$ along with IL-6, transforming growth factor (TGF) $\beta 1$, matrix metalloproteinases (MMPs) and ERK in ultraviolet-induced photoradiation. ${ }^{74}$

Mustard seeds are mainly known for their proinflammatory activity although reports of its effectiveness against carrageenan-induced paw edema in rats are also found. ${ }^{75-77}$ Sinapsis semen obtained from mustard was also effective against acute and chronic models of inflammation in mice. $^{78}$

\section{Protection against nephrotoxicity}

$N$. sativa oil was found to be nephroprotective as it lowered serum creatinine levels and blood urea nitrogen by itself or synergistically with Vitamin C. Black cumin/thymoquinone protected kidney against chemical-induced nephrotoxicity and against ischemia-perfusion damage by preventing renal malfunctions, morphological flaws and balancing the biochemical parameters. ${ }^{79,80}$ Fenugreek treatment significantly reduced diabetic nephropathy symptoms represented by the reduced levels of blood glucose, improved renal functions, suppressed extracellular matrix accumulation, as well as the coordinately relieved oxidant stress together with the restrained TGF- $\beta 1 /$ connective tissue growth factor signaling pathway. ${ }^{81}$ Laroubi et al. proved that fenugreek can be used in the treatment of patients with calcic urolithiasis. ${ }^{82}$ Cumin seeds decreased the increased levels of serum urea and creatinine mostly against gentamycin-induced nephrotoxicity, but detailed study is yet to be done. ${ }^{83}$ Kumar et al. 2011 found that it is also effective against profenofos-induced nephrotoxicity. ${ }^{84}$ A study claimed that fennel was neither nephrotoxic nor nephroprotective while other studies showed that aqueous extract of fennel seeds prevented renal damage by normalizing renal markers such as serum creatinine and urea induced by gentamycin or sodium valproate. ${ }^{85-87}$ Treatment with fennel oil also reduced lesions and edema induced by chemicals along with morphological improve- ment of the kidney tubules and tissues. ${ }^{87}$ Mustard was reported to be nephrotoxic as it caused increased changes in the normal histology of the kidney with increasing dose. ${ }^{88}$

\section{Effect on central nervous system}

Cumin and black cumin have profound effects on the central nervous system. Daily administration of cumin increased cognition and inhibited stress as studied by the conditioned avoidance response using Cook's pole climbing apparatus, estimation of urinary vanillylmandelic acid and ascorbic acid after forced swimming, respectively. ${ }^{89}$ The occurrence of spontaneous activity induced by pentylenetetrazol was decreased by cumin oil, suggesting its antiepileptic activity. ${ }^{90}$ The essential oil (especially the cuminaldehyde fraction) has an inhibitory effect on the fibrillation of $\alpha-\mathrm{SN}$, which is a critical process in the pathophysiology of several neurodegenerative diseases, especially Parkinson's disease. ${ }^{91}$

The aqueous and methanol extracts of $N$. sativa have a significant impact on central nervous system. ${ }^{92}$ Black cumin administration helps to improve learning and memory and reduce anxiety. ${ }^{93}$ Thymoquinone was also effective as an antianxiety drug as it modulates gamma aminobutyric acid (GABA) and NO levels, indicating the involvement of NO-cyclic guanosine monophosphate and GABAergic pathways. ${ }^{94}$ Locomotor activity and grip strengths of rats were improved considerably in middle cerebral artery occluded rats pretreated with aqueous and hydroalcoholic extracts of $N$. sativa. ${ }^{95}$

Fenugreek seeds are known to protect mice from peripheral neuropathy, a disorder commonly associated with diabetes patients, by increasing the nerve conduction velocities and restoring the axon fibers, but its consumption during pregnancy can cause neurological disorders in the next generation such as reduction in the weight of the brain and changes in locomotor activity and motor coordination. ${ }^{96,97}$ Diosgenin and trigonelline, present in fenugreek seeds, are also reported to have antidepressant activity and improve locomotor activity. ${ }^{98}$

Studies are few regarding the effect of fennel on the central nervous system. Ethanolic extract of fennel seeds provided neuroprotection by decreasing amyloid precursor proteins and oxidative stress induced by lead. ${ }^{99}$ In one study, fennel oil is reported to have antidepressant activity without some of the side effects associated with synthetic drugs available for the treatment of depression. ${ }^{100}$

Mustard seeds act as mostly as an irritant instead of protecting the central nervous system. Mustard oil has been reported to activate the adrenoreceptors present in the neurons of the medullary dorsal horn of the brain causing sensitization. ${ }^{101}$ It also activates the neurons of the thalamus. ${ }^{102}$

\section{Antitumorigenic}

All five seeds and/or their active ingredients exhibited antitumor activity mainly by apoptosis. Cumin can inhibit chemical-induced stomach tumorigenesis, uterine cervix tumorigenesis and hepatoma in mice. ${ }^{103}$ Cancer chemopreventive potentials of cumin seed could be attributed to its ability to modulate carcinogen metabolism as it augmented cytochrome P-450, cytochrome b5 and reduced glutathione S-transferase, DT diaphorase activity. ${ }^{103}$ Cumin also destroyed Hela cells and decreased the incidence of both benzo $[a]$ pyrene-induced neoplasia and 3'-methyl-4-dimethylaminoazobenzene-induced hepatomas in Wistar rats. ${ }^{104}$ Cuminaldehyde is also known to reduce the size of tumor and activate proapoptotic caspases and other apoptotic proteins such as B-cell lymphoma 2 (Bcl-2), but studies have not been done in C. cyminum but Cinnamomum verum. ${ }^{105,106}$

Antitumor activity of methanolic extract of $F$. vulgare was evaluated against B16F10 melanoma cell line by trypan blue exclusion assay for cell viability. ${ }^{107}$ Anethole is the principal active component of fennel seeds which has exhibited anticancer activity by increasing survival time, 
reducing tumor weight and reducing the volume and body weight of the Ehrlich ascites tumor-bearing mice. It also produced a significant cytotoxic effect in the Ehrlich ascites tumor cells, reduced the levels of nucleic acids and malondialdehyde and increased GSH concentrations. ${ }^{108}$

Fenugreek seed extract significantly inhibited 7,12-dimethyl benz(a)anthracene-induced mammary hyperplasia and Ehrlich ascites carcinoma cells induced cancer. ${ }^{109,110}$ It exhibited growth inhibitory effects on breast, pancreatic and prostate cancer cell lines but not on primary prostate or immortalized prostate cells. ${ }^{111} \mathrm{~A}$ diet containing fenugreek seed powder decreased colon tumor incidence. ${ }^{53}$ Diosgenin and trigonelline obtained from fenugreek seeds both show anticancer activity, but diosgenin seems to be more potent anticancer agent as greater number of studies reported its activity against various types of cancer. Diosgenin exhibited anticancer activity both in vitro and in vivo by reducing tumor size and activating the proapototic pathways along with a decrease in the antiapoptotic pathways. ${ }^{112}$ Trigonelline also inhibited cancer by inhibiting the Nrf-2 protein among others, but the experiments were done with trigonelline obtained from other sources and not exclusively fenugreek. ${ }^{113}$

Crude oil of $N$. sativa reduced tumor formation in the lungs and different parts of the alimentary canal in rat multi-organ carcinogenesis model after exposure to five different carcinogens. ${ }^{114}$ Thymoquinone was effective against a number of cancer cells and cell lines. ${ }^{115,116}$ The antitumor activity is mediated by the downregulation of NF- $\kappa \mathrm{B}$, vascular endothelial growth factor, Bcl-2, mucin-4, MMP-9 and activation of caspases, mitogen-activated protein kinase, c-Jun- $\mathrm{NH}(2)$ pathways, leading to apoptosis of tumor cells. ${ }^{115,116}$

3-butenyl isothiocyanate isolated from B. juncea was found to be effective against the human cancer prostrate cell lines by inducing apoptosis. ${ }^{117}$ AITC isolated from mustard seeds inhibited cell proliferation and reduced bladder cancer in two cell lines by two different mechanisms; in RT4 cells, it mainly acted via the classical Bcl-2 associated X/Bcl-2 pathway, while in T24 cells, AITC modulated the activities of anillin actin binding protein (related to cytokinesis) and S100 calcium binding protein $\mathrm{P}^{118}$

\section{Effect on platelet function/cardiovascular activity}

Cumin and fennel inhibited platelet aggregation induced by arachidonic acid, collagen, etc. Cumin inhibited thromboxane B2 production and increased the formation of lipoxygenase-derived products. ${ }^{119}$ Decreased paraxonase activity is linked with heart diseases and cumin increased the activity of paraxonase in patients with high cholesterol. ${ }^{120}$ Furthermore, cumin along with lime promoted weight loss, decreased triglycerides and low-density lipoproteins (LDLs), which in increased quantities along with obesity can lead to coronary diseases. ${ }^{121}$

Elevated serum cholesterol, LDL and triglycerides level are major causes of cardiovascular diseases. ${ }^{122}$ Fennel seeds decreased LDLs, increased high-density lipoproteins (HDLs) and also improved the antioxidant enzymes in rats whose diet was high on fats, thus preventing hyperlipidemia and chronic heart diseases. ${ }^{123,124}$ The essential oil and anethole from F. vulgare displayed NO-independent vasorelaxant activity at antiplatelet concentrations, prevented platelet aggregation induced by various reagents and prevented paralysis by its antithrombic activity. ${ }^{125}$ $N$. sativa has favorable effects on the lipid profile and endothelial dysfunction. It inhibited platelet aggregation and provided protection to the heart against chemical reagents as well as against hyperhomocysteinemia. Controversy exists about its effect in lowering blood pressure and heart rate. ${ }^{126}$ The cardioprotective property of Nigella is mainly due to thymoquinone. ${ }^{126}$ Thymoquinone isolated from N. sativa prevented diesel exhaust particle-induced decrease of blood pressure and leukocytosis and increased platelet numbers and prothrombotic events but not platelet aggregation. ${ }^{127}$
Fenugreek seeds reduced myocardial necrosis by decreasing troponin level, increasing activities of cardiac membrane-bound $\mathrm{Na}+, \mathrm{K}+$-ATPase and $\mathrm{Ca} 2+-\mathrm{ATPase}$, reducing lipid peroxidation and increasing levels of antioxidant enzymes. ${ }^{128}$ It also decreased NO production, increased PUFA to SFA ratio, increased marker enzymes of the heart and decreased oxidative stress in heart tissues, thus providing cardioprotection in normal and in diabetic rats. ${ }^{129}$ Trigonelline obtained from fenugreek increased weight of the heart, restored degenerative changes in myocardium and improved cardiac markers and antioxidant system along with reduction in stress proteins Hsp27 and $\alpha \mathrm{B}$ crystalline in isoproterenolinduced myocardial injury. ${ }^{130}$ Diosgenin also offered cardioprotection by modulating protein kinase $\mathrm{A}$ and $\mathrm{p} 38$ pathways. ${ }^{131}$

Regular ingestion of mustard oil provided protection against myocardial infarction. ${ }^{132}$ Mustard oil extract containing alpha-linolenic acid reduced the risk of coronary artery disease. ${ }^{133}$ Another study claimed that subacute dose of mustard seed extract can cause cardiotoxicity which is evident from the histological changes in the heart tissue. ${ }^{134}$

\section{Antidiabetic effect}

All five seeds have antidiabetic effects and lowered blood glucose levels and augmented serum insulin levels mainly in streptozotocin- or alloxan-induced animals. Oral administration of cumin reduced blood glucose levels, glucosuria, blood urea levels and excretion of urea and creatinine in diabetic animals. ${ }^{135}$ It also resulted in a significant reduction in plasma and tissue cholesterol, phospholipids, free fatty acids and triglyceride. ${ }^{136}$ Cumin was also able to lower blood glucose without causing hypoglycemia or $\beta$-cell burnout. ${ }^{137}$ Cuminaldehyde and cuminol were identified as potent insulinotropic components. ${ }^{137}$

Fenugreek seeds lowered blood glucose levels, plasma glucagons and somatostatin levels and improved intraperitoneal glucose tolerance; carbohydrate-induced hyperglycemia also was found to be reduced. ${ }^{138}$ The hypoglycemic effect of fenugreek has been especially documented in humans and animals with type 1 and type 2 diabetes mellitus. ${ }^{139}$ The galactomannan-rich-soluble fiber fraction of fenugreek, diosgenin and amino acid 4-hydroxyisoleucine may be responsible for the antidiabetic and insulinotropic activity of the seeds. In vitro studies have indicated that this amino acid causes direct pancreatic $\beta$-cell stimulation. ${ }^{140}$ Trigonelline is also reported to reduce blood glucose levels and biochemical parameters associated with diabetes along with improvement in insulin level. ${ }^{141}$

In streptozotocin-induced rats, $N$. sativa significantly improved carbohydrate metabolism individually and in combination with alpha-lipoic acid and L-carnitine. ${ }^{142}$ The aqueous extract and thymoquinone reduced diabetes-induced increase in tissue malondialdehyde and reduced streptozotocin-induced mitochondrial and nuclear abnormalities, thymoquinone being more effective. ${ }^{143} \mathrm{~N}$. sativa treatment reduced diabetes by protecting and preserving beta-cell integrity. ${ }^{144}$ It showed synergistic effect in improving bone mass, connectivity, biochemical behavior and strength in diabetic rats. ${ }^{145} \mathrm{~N}$. sativa oil was effective as a supplement in patients who have developed insulin resistance syndrome. ${ }^{146}$ It exerts an insulin-sensitizing action by enhancing ACC phosphorylation and muscle Glut4 content.

Administration of the aqueous extract of $F$. vulgare to diabetic rats corrected the hyperglycemia and the levels of hemoglobin A1c, decreased total cholesterol, triglycerides, LDL, VLDL levels and increased HDL levels. ${ }^{147}$ Benzene, butanol and ethyl acetate fractions obtained from fennel seeds also improved diabetes by inhibiting alphaglucosidase enzyme. ${ }^{148}$

A significant dosage-dependent augmenting effect of the mustard seed extract on the serum insulin was recorded in both short-term and long-term diabetic rats. ${ }^{149}$ Another study reported that $B$. juncea reduced 
glucose, cholesterol and insulin levels induced by fructose but could not bring them back to normal levels. ${ }^{150}$ Grover et al. have reported that antihyperglycemic activity of mustard is evident in alloxan-induced rats but not in streptozotocin-induced rats. ${ }^{151}$

\section{Hepatoprotective activity}

The seeds of Panch phoron have hepatoprotective activity. Methanol and hexane extracts of fennel seeds provided protection against carbon tetrachloride-induced hepatotoxicity by decreasing the levels of alanine aminotransferase (ALT), alkaline phosphatase (ALP), serum aspartate aminotransferase (AST) and total bilirubin (TB). According to Ozbek et al. $d$-limonene and $\beta$-myrcene of essential oil of $F$. vulgare seeds revealed a potent hepatoprotective effect. ${ }^{152}$ Trans-anethole present in fennel essential oil is also considered to be responsible for the hepatoprotective activity of fennel. ${ }^{153}$ Fennel oil also improved liver fibrosis induced by carbon tetrachloride as revealed by histological study of the liver tissues. ${ }^{154}$

Injury caused by hepatic ischemia-reperfusion was protected by the treatment with $N$. sativa. ${ }^{155}$ Essential oil obtained from black cumin not only upregulated the antioxidant enzymes and downregulated liver marker enzymes but also protected the hepatocytes and their DNA from damage. ${ }^{156}$ Thymoquinone is the major component of this essential oil. ${ }^{156}$ Both black cumin and its derivative thymoquinone protected the liver against metal toxicity such as cadmium and lead by attenuating hepatic lipid peroxidation, protein oxidation and increasing depleted antioxidant levels. ${ }^{157}$ Cumin, mixed with Vernonia cinerea, showed hepatoprotective activity by decreasing the levels of serum marker enzymes, bilirubin and creatinine. ${ }^{158}$ Cumin also restored serum glutamic-pyruvic transaminase (SGPT), serum glutamic oxaloacetic transaminase (SGOT), ALP and serum TB to normal. ${ }^{159}$ Besides downregulating the liver function enzymes and upregulating the antioxidant status, cumin and black cumin seeds were also able to restore the damage of the liver tissues induced by cisplatin. ${ }^{160}$ Sheweita et al. reported that cumin and fennel essential oil alone did not cause any significant change in the liver marker enzymes, induced CYP2B1/2 gene expression, increased antioxidant enzymes, reduced CYP2E1 and somewhat ameliorated the histopathology of the liver tissues treated with cyclophosphamide. Fennel reduced while cumin induced the expression of CYP3A4. ${ }^{161}$

Hydromethanolic seed extract of $B$. juncea exhibited hepatoprotective activity against acetaminophen toxicity and restored the elevated levels of liver indices to normal values in hepatocarcinoma cell line (HepG2) by the reduction of ROS. ${ }^{162}$ Ethanol and pet ether extract of $B$. juncea not only decreased the enzymes commonly measured during liver function tests and bilirubin but also improved changes in the histology of liver tissue induced by carbon tetrachloride. ${ }^{163}$

The hepatoprotective activity of fenugreek was evaluated by histopathological studies of the liver section, testing of biochemical parameters such as SGOT, SGPT and serum bilirubin. ${ }^{164}$ Fenugreek reduced activities of serum AST, ALT, lactate dehydrogenase and ALP, lipid peroxidation and increased activities of hepatic antioxidant enzymes - glutathione reductase, glutathione-S-transferase and glutathione peroxidase. ${ }^{165}$ Treatment with fenugreek seed extracts besides normalizing damaged liver tissues, also upregulated the mRNA expression of farnesoid X receptor, an important transcription factor used in bile production and transportation. ${ }^{166}$ Trigonelline and diosgenin are also found to have hepatoprotective properties. ${ }^{167}$

\section{Gastroprotective activity}

Oral administration of essential oil in $F$. vulgare provided significant protection toward ethanol-induced gastric lesions in rats. ${ }^{168}$ Anethole exerted its gastroprotective effects by inhibiting gastric lesions and improving gastric secretion without modifying mucous secretion. ${ }^{169}$ Fenugreek seeds are assumed to have a stimulating effect on the digestive process, which could be linked to its gastroprotective effect as it decreases gastric ulcer, acidity, gastric NO and malondialdehyde levels. ${ }^{168}$ Trigonelline is reported to reduce mucosal injury in indomethacin-induced gastric tissue through its anti-inflammatory and antiapoptotic properties. ${ }^{170}$ In one study, cumin enhanced amylase (both pancreatic and intestinal) and pancreatic trypsin activity while fenugreek decreased both, but both enhanced chymotrypsin. When single dose was given, both reduced all of the above-mentioned enzymes. ${ }^{171}$

Thymoquinone from black cumin has gastroprotective mechanisms via inhibition of the proton pump, acid secretion and neutrophil infiltration while enhancing mucin secretion and NO production. ${ }^{172}$ An aqueous suspension of seeds and thymoquinone prevented gastric ulcer and gastric acid secretion induced by necrotizing agents and restored mucous content of gastric wall. ${ }^{173}$ Thymoquinone may serve as a therapeutic agent in the treatment of inflammatory bowel disease as researchers found that the same could prevent and improve murine dextran sodium sulfate-induced colitis. ${ }^{174}$

\section{Pulmonary and antiasthmatic activity}

Ethanol extract and essential oil from $F$. vulgare exhibited bronchodilatory activity on contracted tracheal chains of guinea pig. The potassium channel opening effect of fennel may contribute to its relaxant effect. ${ }^{175}$ Moreover, anethole bears a striking resemblance to the catecholamines epinephrine, norepinephrine and dopamine. This structural similarity appears to be responsible for the various sympathomimetic activities of F. vulgare such as bronchodilatory effect. ${ }^{176}$

Various fractions and extracts of $N$. sativa inhibited $\mathrm{Ba}^{++}$carbachol- and leukotriene-induced trachea contractions, had a relaxant effect on tracheal chains, prevented tracheal responsiveness and lung inflammation in mustard gas exposed experimental animals and reduced the severity of lung damage in hyperoxia. ${ }^{177,178} \mathrm{~N}$. sativa treatment inhibited inflammatory pulmonary responses by inhibiting granuloma, infiltration of cells and necrosis. ${ }^{179}$ It also had prophylactic effect on asthmatic diseases, which it controls by improving the symptoms of asthma and improving pulmonary function tests. ${ }^{180}$ Thymoquinone is responsible for the protective effect of black cumin and does so by modulating the adenosine receptors. ${ }^{181}$

Cumin seeds have antitussive effects as macerated and aqueous extract reduced the frequency of coughs in guinea pigs. ${ }^{182}$ Seed extract of fenugreek suppressed pulmonary fibrosis by upregulating Nrf-2 and downregulating the pro-inflammatory and apoptotic markers of the lung. ${ }^{71}$ Fenugreek also has antiasthmatic properties as it improved forced expiratory volume, peak expiratory flow and maximal expiratory volume in asthma patients along with a reduction in IL-4 levels. ${ }^{183}$ Diosgenin from fenugreek ameliorates acute lung injury by downregulating the mediators of inflammation and signaling pathways (NF- $\mathrm{kB}$ and p38). ${ }^{184}$

\section{CONCLUSION}

This review discusses separately the pharmacological and therapeutic effects of Panch phoron or the mixture of five spices as promising herbal drugs because of its ready availability, use in our daily life, safety and effectiveness. Apart from the above-stated properties, the seeds also have other properties, i.e., antiosteoporotic effect and protection of erythrocytes by cumin, antihirutism and estrogenic activity by fennel, cholesterol-lowering effect of fenugreek and testicular protective activity of black cumin. . $^{185-189}$

The properties are mainly seen in the crude extract or in one or two active components of the various seeds. However, the immense traditional use and pharmacological activities indicate that there is still scope 
for their exploration. Further, in most cases, the mechanism of action needs to be underlined. The role of geographical factors and seasonal variation in influencing the chemical constituents responsible for the activity needs to be studied. The synergistic/antagonistic/cascading effects of one seed on another, when present together is an important area of study. Only after these studies can we scientifically validate the use of these spices in our daily life.

\section{ACKNOWLEDGEMENT}

I hereby express my thanks to my Ph. D. guide, Department of Pharmacology, IPGME\&R, for introducing me to the field of medicinal plants. I also acknowledge the support from Officer-in-charge, Acharya Prafulla Chandra Roy Government College and my departmental colleagues who helped me carry on my work.

\section{CONFLICT OF INTEREST}

The authors declare no conflict of interest.

\section{ABBREVIATIONS}

AITC: Allyl isothiocyanate; ALP: Alkaline phosphate; ALT: Alanine aminotransferase; ANLN: Anillin actin binding protein; AST: Aspartate aminotransferase; B[a]P: Benzo[a]pyrene; BAX: Bcl-2 associated X; Bcl-2: B-cell lymphoma 2; Muc-4: Mucin-4; cGMP: Cyclic guanosine monophosphate; COX-2: Cycloxygenase-2; CTGF: Connective tissue growth factor; DN: Diabetic nephropathy; DT-diaphorase: NAD $(\mathrm{P}) \mathrm{H}$ dehydrogenase; ECM: Extracellular matrix; ERK: Extracellular signal regulated kinase; GABA: Gamma amino butyric acid; HbA1c: Hemoglobin A1c; Hep2: Hepatocarcinoma cell line; HDL: High-density lipoprotein; IL: Interleukin; IFN: Interferon; JNK: Jun N-terminal kinase; LDL: Low-density lipoproteins; LPS: Lipopolysaccharide; MAP kinase: Mitogen-activated protein kinase; 3'MeDAB: 3'-methyl-4-dimethylaminoazobenzene; MMP: Matrix metalloproteinase; NF-кB: Nuclear factor-kappa B; RAW 264.7: Murine macrophage cell line; SGOT: Serum glutamic oxaloacetic transaminase; SGPT: Serum glutamic pyruvic transaminase; S100P: S100 calcium binding protein P; NO: Nitric oxide; TB: Total bilirubin; TGF: Transforming growth factor; TLR: Toll-like receptor; TNF: Tumor necrosis factor, WHO: World Health Organization, VEGF: Vascular endothelial growth factor; VLDL: Very low-density lipoproteins, VMA: Vanillylmandelic acid.

\section{SUMMARY}

Panch phoron, a mixture of five different spices, namely cumin, fennel, fenugreek, mustard and black cumin seeds, is used daily for tempering food throughout India, especially in the eastern region. Each of the five seeds has myriad pharmacological properties, some of which has been included in this study. Cumin, fennel, fenugreek and black cumin have antimicrobial properties as they inhibited bacterial and fungal growth. All the seeds displayed antioxidant activity by preventing the production of free radicals and/or by reducing lipid peroxidation or upregulating the antioxidant enzymes. Cumin, fenugreek, black cumin and fennel have anti-inflammatory properties and provide protection against nephrotoxicity. Mustard, on the other hand, displayed proinflammatory properties. Cumin and black cumin were effective in improving learning and memory and also reducing anxiety levels. All of them were antitumorigenic and prevented tumor growth and progression mainly by upregulating apoptotic pathways. All of them show antidiabetic effect mainly by reducing blood glucose levels. The seeds show hepatoprotective and moderate cardiovascular activity. Black cumin, fenugreek and fennel have gastroprotective activity. Fennel and black cumin are also proven to have antiasthmatic activity. Various other pharmacological properties of the seeds were studied, but there is scope for further exploration and scientific validation, regarding their properties with respect to seasonal and geographical variations, identification of their active principles and combined effect of the seeds taken together.

\section{REFERENCES}

1. Abd-Awn B, Al-Dhaher Z, Al-Dafaai R. The effect of black seed oil extracts on mutans streptococci in comparison to chlorhexidine gluconate (in vitro). J Baghdad Coll Dent. 2012;24(4):126-31.

2. World Health Organization. Traditional Medicine Strategy, 2002-2005. Geneva (CH): WHO Publication. 2002;1-6.

3. Raghavan S. Handbook of Spices, Seasonings and Flavorings. $2^{\text {nd }}$ ed. Hoboken: CRC Press. 2007

4. Wikipedia Contributors. Panch Phoron. Wikipedia, The Free Encyclopedia. 2005. Available from: https://en.wikipedia.org/w/index.php?title=Panch_ phoron\&oldid $=889721249$

5. Pritha S. Paanch Phoron: The Seduction of Five Little Seeds. 2016. Available from: http://www.expressfoodie.com/main-course/paanch-phoron-seductionfive-little-seeds.

6. Farrell KT. Spices, Condiments and Seasonings. Westport, Connecticut: The AVI Publishing Co., Inc. 1985;98-100.

7. Parthasarathy VA, Chempakam B, Zachariah TJ. Chemistry of spices. CAB Int. 2008;211-26.

8. Prajapati ND, Purohit SS, Sharma AK, Kumar T. A Hand Book of Medicinal Plant: a Complete Source Book. India. Agrobios. 2003;928.

9. PDR for Herbal Medicines. Montvale: Medical Economics Company, Inc. 2000;237-8.

10. Shivakumar SI, Shahapurkar AA, Kalmath K, Shivakumar B. Antiinflammatory activity of fruits of Cuminum cyminum linn. Pharm Lett. 2010;2(1):22-4.

11. Zargari A. Medicinal Plants. $5^{\text {th }}$ ed. Tehran: Tehran University Publications. $2001 ; 2$.

12. Rahimi R, Ardekani MR. Medicinal properties of Foeniculum vulgare mill. In traditional Iranian medicine and modern phytotherapy. Chin J Integr Med. 2013;19(1):73-9.

13. Kirtikar KR, Basu BD. In Indian Medicinal Plants. International Book Distributors. 1999;7.

14. Badgujar SB, Patel VV, Bandivdekar AH. Foeniculum vulgare mill: A review of its botany, phytochemistry, pharmacology, contemporary application and toxicology. Biomed Res Int. 2014;2014:842674.

15. Betty RI. The many healing virtues of fenugreek. Spice India. 2008;1:17-9.

16. Srinivasan K. Fenugreek (Trigonella foenum-graecum): A review of health beneficial physiological effects. Food Rev Int. 2006;22(2):203-24.

17. Yadav R, Kaushik R, Gupta D. The health benefits of Trigonella foenum-graecum: A review. Int J Eng Res Appl. 2011;1(1):32-5.

18. Al-Shehbaz IA. A generic and tribal synopsis of the Brassica juncea (Cruciferae) Taxon. 2012;61(5):931-54.

19. Mishra A, Dash P, Murthy PN, Siddique HH, Kushwaha P. A classical review on Rajika (Brassica juncea) research and reviews. J Bot Sci. 2012;1(1):18-23.

20. Duke JA, Wain KK. Medicinal Plants of the World. Computer Index with More Than 85,000 Entries. Plants Genetics and Germplasm Institute. Beltsville, Maryland: Agriculture Research Service. 1981;3.

21. Ouyang SW, Zhao KJ, Feng LX, Chye ML, Ram S. BjCHI1 from Brassica juncea displays both chitinase and agglutination activity. Sheng Wu Gong Cheng Xue Bao. 2002;18(5):572-7.

22. Perry LM. Medicinal Plants of East and Southeast Asia: attributed Properties and Uses. Cambridge, Massachusetts, United States and London, United Kingdom: The MIT Press. 1980;620

23. Hemingway JS, Schofield HJ, Vaughan JG. Volatile mustard oils of Brassica juncea seeds. Nature. 1961;192(4806):993.

24. Al-Bukhari MI. The collection of authentic sayings of Prophet Mohammad (peace be upon him), division 71 on medicine. Sahi Al-Bukhari. $2^{\text {nd }}$ ed. Ankara: HilalYayinlari. 1976

25. Saha R, Bhupendar K. Pharmacognosy and pharmacology of Nigella sativa: A review. Int Res J Pharm. 2011;2(11):36-9.

26. The Ayurvedic Pharmacopoeia of India, Part 1. New Delhi: Ministry of Health and Family Welfare. 1989;119-20.

27. Stefanini MB, Figueiredo RO, Ming LC, Júnior AF. Antimicrobial activity of the essential oils of some spice herbs. International Conference on Medicinal and Aromatic Plants (Part II). 2001;597:215-6.

28. Con AH, Ayar A, Gokalp HY. Antimicrobial activity of the essential oils extracted from some spices. Food. 1998;23:171-5.

29. Kaur GJ, Arora DS. Antibacterial and phytochemical screening of Anethum graveolens, Foeniculum vulgare and Trachyspermum ammi. BMC Complement Altern Med 2009;9(1):30.

30. Liu Q, Meng X, Li Y, Zhao CN, Tang GY, Li HB, et al. Antibacterial and antifungal 
activities of spices. Int J Mol Sci. 2017;18(6):E1283

31. Jirovetz L, Buchbauer G, Stoyanova AS, Georgiev EV, Damianova ST. Composition, quality control and antimicrobial activity of the essential oil of cumin (Cuminum cyminum L.) seeds from Bulgaria that had been stored for up to 36 years. Int J Food Sci Technol. 2005;40(3):305-10.

32. Walli RR, Al-Musrati RA, Eshtewi HM, Sherif FM. Screening of antimicrobia activity of fenugreek seeds. Pharm Pharmacol Int J. 2015;2(4):28-31.

33. Morsi NM. Antimicrobial effect of crude extracts of Nigella sativa on multiple antibiotics-resistant bacteria. Acta Microbiol Pol. 2000;49(1):63-74.

34. Chaieb K, Kouidhi B, Jrah H, Mahdouani K, Bakhrouf A. Antibacterial activity of thymoquinone, an active principle of Nigella sativa and its potency to prevent bacterial biofilm formation. BMC Complement Altern Med. 2011:11:29.

35. Akkoyun HT, Dostbil N, Kiran O. Antimicrobial activity of black mustard seed. (Brassica nigra L.). Asian J Chem 2007;19(7):5533-6.

36. Khan A, Shahid S, Jameel M, Ahmed A. In vitro antibacterial, antifungal and GC-MS analysis of seeds of mustard brown. Int J Pharm Chem. 2016;6(4):107-15.

37. Luciano FB, Holley RA. Enzymatic inhibition by allyl isothiocyanate and factors affecting its antimicrobial action against Escherichia coli 0157:H7. Int J Food Microbiol. 2009;131(2-3):240-5

38. Hadian J, Ghasemnezhad M, Ranjbar H, Frazane M, Ghorbanpour M. Antifunga potency of some essential oils in control of post-harvest decay of strawberry caused by Botrytis cinerea, Rhizopus stolonifer and Aspergillus niger. J Essent Oil Bear PI 2008;11(5):553-62.

39. Anwar F, Ali M, Hussain Al, Shahid M. Antioxidant and antimicrobial activities of essential oil and extracts of fennel (Foeniculum vulgare Mill.) seeds from Pakistan. Flavour Fragr J. 2009;24(4):170-6.

40. Thakur N, Sareen N, Shama B, Jagota K. Studies on in vitro antifungal activity of Foeniculum vulgare Mill. against spoilage fungi. Global J Bio Sci Bio Technol. 2013;2(3):427-30

41. Haouala R, Hawala S, El-Ayeb A, Khanfir R, Boughanmi N. Aqueous and organic extracts of Trigonella foenum-graecum $\mathrm{L}$. inhibit the mycelia growth of fungi. $J$ Environ Sci. 2008;20(12):1453-7.

42. EINour ME, Ali AM, Saeed BE. Antimicrobial activities and phytochemica screening of callus and seeds extracts of Fenugreek (Trigonella foenum-graecum) Int J Curr Microbiol App Sci. 2015;4(2):147-57.

43. Bita A, Rosu AF, Calina D, Rosu L, Zlatian O, Dindere C, et al. An alternative treatment for Candida infections with Nigella sativa extracts. Eur J Hosp Pharm. 2012;19(2):162-3.

44. Rogozhin EA, Oshchepkova YI, Odintsova TI, Khadeeva NV, Veshkurova ON Egorov TA, et al. Novel antifungal defensins from Nigella sativa L. seeds. Plant Physiol Biochem. 2011;49(2):131-7.

45. Kumar V, Thakur AK, Barothia ND, Chatterjee SS. Therapeutic potentials of Brassica juncea: An overview. Int J Genuine Tradit Med 2011;1(1):1-17.

46. Guan Y, Ramalingam S, Nagegowda D, Taylor PW, Chye ML. Brassica juncea chitinase bjCHI1 inhibits growth of fungal phytopathogens and agglutinates gram-negative bacteria. J Exp Bot. 2008;59(12):3475-84

47. Sheikh BY, Taha MM, Koko WS, Abdelwahab SI. Antimicrobial effects of thymoquinone on Entamoeba histolytica and Giardia lamblia. Pharmacogn J. 2015;8(2):168-70

48. Forouzanfar F, Bazzaz BS, Hosseinzadeh H. Black cumin (Nigella sativa) and its constituent (thymoquinone): A review on antimicrobial effects. Iran J Basic Med Sci. 2014;17(12):929-38.

49. Khadse CD, Kakde RB. In vitro anthelmintic activity of Fenugreek seeds extract against Pheritimaposthuma. Int J Res Pharm Sci. 2010;1(3):267-9.

50. Lavanya B, Ramya Krishna PS, Nagarjuna S, Reddy YP. In vitro comparative study of anthelmintic activity of Brassica juncea and Brassica oleracea. J Pharm Res. 2011;4(9):2907-9

51. Naidu MM, Shyamala BN, Naik PJ, Sulochanamma G, Srinivas P. Chemica composition and antioxidant activity of the husk and endosperm of fenugreek seeds. Food Sci Technol. 2010;44(2):451-6.

52. Bukhari SB, Muhammad IB, Shahabuddin M. Antioxidant activity from the extract of fenugreek seeds. Pak J Anal Environ Chem. 2008;9(2):78-83.

53. Devasena T, Venugopal MP. Fenugreek seeds modulate 1,2-dimethylhydrazineinduced hepatic oxidative stress during colon carcinogenesis. Ital J Biochem. 2007;56(1):28-34

54. Rebey IB, Kefi S, Bourgou S, Ouerghemmi I, Ksouri R, Tounsi MS, et al. Ripening stage and extraction method effects on physical properties, polypheno composition and antioxidant activities of cumin (Cuminum cyminum L.) seeds. Plant Foods Hum Nutr. 2014;69(4):358-64.

55. Surya D, Vijayakumar RS, Nalini N. Oxidative stress and the role of cumin (Cuminum cyminum Linn.) in alloxan-induced diabetic rats. J Herbs Spices Med Plants. 2005;11(3):127-39.

56. DeMartino L, DeFeo V, Fratianni F, Nazzaro F. Chemistry, antioxidant, antibacterial and antifungal activities of volatile oils and their components. Nat Prod Commun. 2009:4(12):1741-50.

57. Oktaya M, Gulcin I, Kufrevioglu O. Determination of in vitro antioxidant activity of fennel (Foeniculum vulgare) seed extracts. Lebensm Wiss Technol. 2003;36(2):263-71.
58. Mannaa F, Ibrahim NA, Ibrahim SS, Abdel-Wahhab KG, Hassan NS Mohammed SG. Preventive role of chamomile flowers and fennel seeds extracts against liver injury and oxidative stress induced by an immunosuppressant drug in rats. Hepatoma Res. 2015;1:125-35.

59. Mohamad RH, El-Bastawesy AM, Abdel-Monem MG, Noor AM, Al-Mehdar HA Sharawy SM, et al. Antioxidant and anticarcinogenic effects of methanolic extract and volatile oil of fennel seeds (Foeniculum vulgare). J Med Food. 2011;14(9):986-1001.

60. Kazem YM, Moaty MA, El-Shebini SM, Ahmed NH, Fouad S, Tapozada ST. Constipation, oxidative stress in obese patients and their impact on cognitive functions and mood, the role of diet modification and Foeniculum vulgare supplementation. J Biol Sci. 2017:17(7):312-9.

61. Gendy E, Hessien M, Abdel SI, Moradm ME, Magrabym K, Ibrahimm HA et al. Evaluation of the possible antioxidant effects of soybean and Nigella sativa during experimental hepatocarcinogenesis by nitrosamine precursors. Turk J Biochem. 2007;32:5-11.

62. Hosseinzadeh H, Parvardeh S, Asl MN, Sadeghnia HR, Ziaee T. Effect of thymoquinone and Nigella sativa seeds oil on lipid peroxidation level during global cerebral ischemia-reperfusion injury in rat hippocampus. Phytomedicine. 2007:14(6):621-7.

63. Dua A, Chander S, Agrawal S, Mahajan R. Antioxidants from defatted Indian Mustard (Brassica juncea) protect biomolecules against in vitro oxidation. Physiol Mol Biol Plants. 2014;20(4):539-43.

64. Kumari N, Avtar R, Sharma B, Thakral N. Antioxidant potential in seed meal of different Indian Mustard genotypes. J Oilseed Brassica. 2016;7(1):63-7.

65. Bhat SP, Rizvi W, Kumar A. Effect of Cuminum cyminum L seed extracts on pain and inflammation. J Natl Remedies. 2014:14(2):186-92.

66. Wei J, Zhang X, Bi Y, Miao R, Zhang Z, Su H. Anti-inflammatory effects of cumin essential oil by blocking JNK, ERK and NF-KB signaling pathways in LPS-stimulated RAW 264.7 cells. Evid Based Complement Alternat Med. 2015;2015:474509

67. Shuid AN, Mohamed N, Mohamed IN, Othman F, Suhaimi F, Mohd RES, et al. Nigella sativa: A potential antiosteoporotic agent. Evid Based Complemen Alternat Med 2012:2012:696230.

68. Umar S, Zargan J, Umar K, Ahmad S, Katiyar CK, Khan HA. Modulation of the oxidative stress and inflammatory cytokine response by thymoquinone in the collagen induced arthritis in wistar rats. Chem Biol Interact. 2012;197(1):40-6.

69. Pundarikakshudu K, Shah DH, Panchal AH, Bhavsar GC. Anti-inflammatory activity of fenugreek (Trigonella foenum-graecum linn) seed petroleum ether extract. Indian J Pharmacol. 2016;48(4):441-4

70. Vyas S, Agrawal RP, Solanki P, Trivedi P. Analgesic and anti-inflammatory activities of Trigonella foenum-graecum (seed) extract. Acta Pol Pharm. 2008;65(4):473-6.

71. Kandhare AD, Bodhankar SL, Mohan V, Thakurdesai PA. Effect of glycosides based standardized fenugreek seed extract in bleomycin-induced pulmonary fibrosis in rats: Decisive role of Bax, Nrf2, NF-אB, Muc5ac, TNF- $\alpha$ and IL-1 $\beta$. Chem Biol Interact. 2015:237:151-65.

72. Khalili M, Alavi M, Esmaeil-Jamaat E, Baluchnejadmojarad T, Roghani M Trigonelline mitigates lipopolysaccharide-induced learning and memory impairment in the rat due to its anti-oxidative and anti-inflammatory effect. Int Immunopharmacol. 2018;61:355-62.

73. Rezayat SM, Dehpour AR, Motamed SM, Yazdanparast M, Chamanara M Sahebgharani $M$, et al. Foeniculum vulgare essential oil ameliorates acetic acid-induced colitis in rats through the inhibition of NF-kB pathway. Inflammopharmacology. 2018;26(3):851-9.

74. Sun Z, Park SY, Hwang E, Park B, Seo SA, Cho JG, et al. Dietary Foeniculum vulgare mill extract attenuated UVB irradiation-induced skin photoaging by activating of Nrf2 and inhibiting MAPK pathways. Phytomedicine. 2016;23(12):1273-84

75. Fiorentino PM, Cairns BE, Hu JW. Development of inflammation after application of mustard oil or glutamate to the rat temporomandibular joint. Arch Oral Biol. 1999;44(1):27-32.

76. Zhang S, Chiang CY, Xie YF, Park SJ, LuY, Hu JW, et al. Central sensitization in thalamic nociceptive neurons induced by mustard oil application to rat molar tooth pulp. Neuroscience. 2006;142(3):833-42

77. Chouhan YS, Kataria HC, Gosawmi CS. Anti-inflammatory activity of methanolic extract of Brassica juncea seed on carrageenan induced paw edema in rats. Int J Pharm Sci Res. 2014:5(9):3849-51.

78. Xian YF, Hu Z, Ip SP, Chen JN, Su ZR, Lai XP, et al. Comparison of the antiinflammatory effects of Sinapis alba and Brassica juncea in mouse models of inflammation. Phytomedicine. 2018;50:196-204

79. Yildiz F, Coban S, Terzi A, Savas M, Bitiren M, Celik $H$, et al. Protective effects of Nigella sativa against ischemia-reperfusion injury of kidneys. Ren Fail. 2010;32(1):126-31.

80. Uz E, Bayrak O, Uz E, Kaya A, Bayrak R, Uz B, et al. Nigella sativa oil for prevention of chronic cyclosporine nephrotoxicity: An experimental model. Am J Nephrol. 2008;28(3):517-22.

81. Jin Y, Shi Y, Zou Y, Miao C, Sun B, Li C. Fenugreek prevents the development 
of STZ-induced diabetic nephropathy in a rat model of diabetes. Evid Based Complement Alternat Med. 2014;2014:259368.

82. Laroubi A, Touhami M, Farouk L, Zrara I, Aboufatima R, Benharref A. Prophylaxis effect of Trigonella foenum graecum $\mathrm{L}$. Seeds on renal stone formation in rats. Phytother Res. 2007;21(10):921-5.

83. Mahesh CM, Gowda KP, Gupta AK. Protective action of Cuminum cyminum against gentamicin- induced nephrotoxicity. J Pharm Res. 2010;3(4):753-7.

84. Kumar A, Singh JK, Ali M, Kumar R, Kumar A, Nath A, et al. Evaluation of Cuminum cyminum and Coriandrum sativum on profenofos induced nephrotoxicity in Swiss albino mice. Elixir Appl Botany. 2011;39:4771-3.

85. Mazaheri S, Nematbakhsh M, Bahadorani M, Pezeshki Z, Talebi A, Ghannadi AR, et al. Effects of fennel essential oil on cisplatin-induced nephrotoxicity in ovariectomized rats. Toxicol Int. 2013;20(2):138-45

86. Al-Masri SA, Ali WS. The ameliorating effects of fennel powder, extract and oil on gentamicin induced nephrotoxicity in rats. J Am Sci. 2013:9:143-8.

87. Al-Amoudi WM. Protective effects of fennel oil extract against sodium valproateinduced hepatorenal damage in albino rats. Saudi J Biol Sci. 2017;24(4):915-24.

88. Inyang IJ, Eyo AA, OlajideTM, Essien A. Effects of ethanolic extract of Brassica juncea (mustard seed) on the brain and kidney tissues of albino wistar rats. J Biol Agric Healthc. 2014;4(22):75-82.

89. Koppula S, Choi DK. Cuminum cyminum extract attenuates scopolamineinduced memory loss and stress-induced urinary biochemical changes in rats: A noninvasive biochemical approach. Pharm Biol. 2011;49(7):702-8.

90. Janahmadi M, Niazi F, Danyali S, Kamalinejad M. Effects of the fruit essentia oil of Cuminum cyminum linn. (Apiaceae) on pentylenetetrazol-induced epileptiform activity in F1 neurones of helix aspersa. J Ethnopharmacol. 2006;104(1-2): 278-82.

91. Morshedi D, Aliakbari F, Tayaranian-Marvian A, Fassihi A, Pan-Montojo F, Pérez-Sánchez H. Cuminaldehyde as the major component of Cuminum cyminum, a natural aldehyde with inhibitory effect on alpha-synuclein fibrillation and cytotoxicity. J Food Sci. 2015;80(10):H2336-45.

92. Al-NaggarTB, Gómez-Serranillos MP, Carretero ME, Villar AM. Neuropharmacological activity of Nigella sativa L. extracts. J Ethnopharmacol. 2003;88(1):63-8.

93. Perveen T, Abdullah A, Haider S, Sonia B, Munawar AS, Haleem DJ. Long-term administration of Nigella sativa effects nociceotion and improves learning and memory in rats. Pak J Biochem Mol Biol. 2008;41(3):141-3.

94. Gilhotra N, Dhingra D. Thymoquinone produced antianxiety-like effects in mice through modulation of GABA and NO levels. Pharmacol Rep. 2011;63(3):660-9.

95. Akhtar M, Maikiyo AM, Khanam R, Mujeeb M, Aqil M, Najmi AK. Ameliorating effects of two extracts of Nigella sativa in middle cerebral artery occluded rat. J Pharm Bioallied Sci. 2012;4(1):70-5.

96. Moghadam FH, Vakili-Zarch B, Shafiee M, Mirjalili A. Fenugreek seed extract treats peripheral neuropathy in pyridoxine induced neuropathic mice. EXCLI J. 2013;12:282-90

97. Khalki L, Bennis M, Sokar Z, Ba-M'hamed S. The developmental neurobehavioral effects of fenugreek seeds on prenatally exposed mice. J Ethnopharmacol 2012;139(2):672-7.

98. Natarajan B, Muralidharan A, Satish R, Dghananjayan R. Neuropharmacological activity of Trigonella foenum graecum Linn. seeds. J Natl Remedies. 2007;7(1):160-5

99. Bhatti S, Ali Shah SA, Ahmed T, Zahid S. Neuroprotective effects of Foeniculum vulgare seeds extract on lead-induced neurotoxicity in mice brain. Drug Chem Toxicol. 2018;41(4):399-407.

100. Perveen T, Emad S, Ahmad S, Batool Z, Yousuf S, Sheikh S, et al. Fennel oil treatment mimics the anti-depressive and anxiolytic effects of fluoxetine without altering the serum cholesterol levels in rats. Pak J Zool. 2017;49(6):2291-7.

101. Wang H, Xie YF, Chiang CY, Dostrovsky JO, Sessle BJ. Central $\alpha$-adrenoceptors contribute to mustard oil-induced central sensitization in the rat medullary dorsal horn. Neuroscience. 2013;236:244-52.

102. Kawamura J, Kaneko T, Kaneko M, Sunakawa M, Kaneko R, Chokechanachaisakul U, et al. Neuron-immune interactions in the sensitized thalamus induced by mustard oil application to rat molar pulp. J Dent Res. 2010;89:1309-14.

103. Gagandeep, Dhanalakshmi S, Méndiz E, Rao AR, Kale RK. Chemopreventive effects of Cuminum cyminum in chemically induced forestomach and uterine cervix tumors in murine model systems. Nutr Cancer. 2003;47(2):171-80.

104. Aruna K, Sivaramakrishnan VM. Anticarcinogenic effects of some Indian plant products. Food Chem Toxicol. 1992;30(11):953-6.

105. Tsai KD, Liu YH, Chen TW, Yang SM, Wong HY, Cherng J, et al. Cuminaldehyde from Cinnamomum verum induces cell death through targeting topoisomerase 1 and 2 in human colorectal adenocarcinoma COLO 205 cells. Nutrients. 2016;8(6):E318.

106. Yang SM, Tsai KD, Wong HY, Liu YH, Chen TW, Cherng J, et al. Molecular mechanism of Cinnamomum verum component cuminaldehyde inhibits cell growth and induces cell death in human lung squamous cell carcinoma NCl-H520 cells in vitro and in vivo. J Cancer. 2016;7(3):251-61.

107. Pradhan M, Sribhuwaneswari S, Karthikeyan D, Minz S, Sure P, Chandu AN et al. In vitro cytoprotection activity of Foeniculum vulgare and Helicteres isora in cultured human blood lymphocytes and antitumour activity against B16F10 melanoma cell line. Res J Pharm Technol. 2008;1(4):450-2.

108. Al-Harbi MM, Qureshi S, Raza M, Ahmed MM, Giangreco AB, Shah AH. Influence of anethole treatment on the tumour induced by Ehrlich ascites carcinoma cells in paw of Swiss albino mice. Eur J Cancer Prev. 1995;4(4):307-18.

109. Amin A, Alkaabi A, Al-Falasi S, Daoud SA. Chemopreventive activities of Trigonella foenum graecum (Fenugreek) against breast cancer. Cell Biol Int. 2005;29(8):687-94

110. Prabhu A, Krishnamoorthy M. Anticancer activity of Trigonella foenum-graecum on Ehrlich ascites carcinoma in Mus musculus system. J Pharm Res. 2010;3(6):1181-3

111. Shabbeer S, Sobolewski M, Anchoori RK, Kachhap S, Hidalgo M, Jimeno A et al. Fenugreek: A naturally occurring edible spice as an anticancer agent. Cancer Biol Ther. 2009;8(3):272-8.

112. Sethi G, Shanmugam MK, Warrier S, Merarchi M, Arfuso F, Kumar AP, et al. Pro-apoptotic and anti-cancer properties of diosgenin: A comprehensive and critical review. Nutrients. 2018;10(5):E645.

113. Arlt A, Sebens S, Krebs S, Geismann C, Grossmann M, Kruse ML, et al. Inhibition of the Nrf2 transcription factor by the alkaloid trigonelline renders pancreatic cancer cells more susceptible to apoptosis through decreased proteasomal gene expression and proteasome activity. Oncogene. 2013:32(40):4825-35

114. Salim El. Cancer chemopreventive potential of volatile oil from black cumin seeds, Nigella sativa L. in a rat multi-organ carcinogenesis bioassay. Oncol Lett. 2010;1(5):913-24.

115. Peng L, Liu A, Shen $Y, X u H Z$, Yang SZ, Ying XZ, et al. Antitumor and anti-angiogenesis effects of thymoquinone on osteosarcoma through the NF-kB pathway. Oncol Rep. 2013;29(2):571-8.

116. Ng WK, Yazan LS, Ismail M. Thymoquinone from Nigella sativa was more potent than cisplatin in eliminating of $\mathrm{SiHa}$ cells via apoptosis with downregulation of $\mathrm{Bcl}-2$ protein. Toxicol in vitro. 2011;25(7):1392-8.

117. Arora R, Kumar R, Mahajan J, Vig AP, Singh B, Singh B, et al. 3-butenyl isothiocyanate: A hydrolytic product of glucosinolate as a potential cytotoxic agent against human cancer cell lines. J Food Sci Technol. 2016;53(9):3437-45.

118. Sávio AL, DaSilva GN, Salvadori DM. Inhibition of bladder cancer cell proliferation by allyl isothiocyanate (mustard essential oil). Mutat Res. 2015;771:29-35.

119. Srivastava KC. Extracts from two frequently consumed spices - cumin (Cuminum cyminum) and turmeric (Curcuma longa) - inhibit platelet aggregation and alter eicosanoid biosynthesis in human blood platelets. Prostaglandins Leukot Essent Fatty Acids. 1989:37(1):57-64

120. Samani KG, Farrokhi E. Effects of cumin extract on oxLDL, paraoxanase activity, FBS, total cholesterol, triglycerides, HDL-C, LDL-C, apo A1 and apo B in in the patients with hypercholesterolemia. Int J Health Sci. 2014;8(1):39-43.

121. Taghizadeh M, Memarzadeh MR, Abedi F, Sharifi N, Karamali F, Fakhrieh Kashan Z. The effect of Cumin cyminum L. Plus lime administration on weight loss and metabolic status in overweight subjects: A randomized double-blind placebo-controlled clinical trial. Iran Red Crescent Med J. 2016;18(8):e34212.

122. Sabzghabaee AM, Dianatkhah M, Sarrafzadegan N, Asgary S, Ghannadi A Clinical evaluation of Nigella sativa seeds for the treatment of hyperlipidemia: A randomized, placebo controlled clinical trial. Med Arch. 2012;66(3):198-200.

123. Rezq AA. Beneficial health effects of fennel seeds (Shamar) on male rats feeding high fat-diet. Med J Cairo Univ. 2012;80(2):101-13.

124. Osman NN, Backer WS, Al-Ahmadi AM. The role of senna and fennel in ameliorating cardiovascular disease in diabetic rats. Am J Pharm Health Res. 2017;5:48-59

125. Tognolini M, Ballabeni V, Bertoni S, Bruni R, Impicciatore M, Barocelli E. Protective effect of Foeniculum vulgare essential oil and anethole in an experimental model of thrombosis. Pharmacol Res. 2007:56(3):254-60.

126. Shabana A, El-Menyar A, Asim M, Al-Azzeh H, Al Thani H. Cardiovascula benefits of black cumin (Nigella sativa). Cardiovasc Toxicol. 2013;13(1):9-21.

127. Nemmar A, Al-Salam S, Zia S, Marzouqi F, Al-Dhaheri A, Subramaniyan D, et al. Contrasting actions of diesel exhaust particles on the pulmonary and cardiovascular systems and the effects of thymoquinone. $\mathrm{Br} \mathrm{J}$ Pharmacol. 2011;164(7):1871-82

128. Mukthamba P, Srinivasan K. Dietary fenugreek (Trigonella foenum-graecum) seeds and garlic (Allium sativum) alleviates oxidative stress in experimenta myocardial infarction. Food Sci Hum Wellness. 2017;6(2):77-87.

129. Pradeep SR, Srinivasan K. Alleviation of cardiac damage by dietary fenugreek (Trigonella foenum-graecum) seeds is potentiated by onion (Allium cepa) in experimental diabetic rats via blocking renin-angiotensin system. Cardiovasc Toxicol. 2018;18(3):221-31.

130. Panda S, Biswas S, Kar A. Trigonelline isolated from fenugreek seed protects against isoproterenol-induced myocardial injury through down-regulation of Hsp27 and $\alpha B$-crystallin. Nutrition. 2013;29(11-12):1395-403.

131. Chen CT, Wang ZH, Hsu CC, Lin HH, Chen JH. In vivo protective effects of diosgenin against doxorubicin-induced cardiotoxicity. Nutrients. 2015;7(6):4938-54

132. Singh RB, Niaz MA, Sharma JP, Kumar R, Rastogi V, Moshiri M, et al. Random ized, double-blind, placebo-controlled trial of fish oil and mustard oil in patients with suspected acute myocardial infarction: The Indian experiment of infarct survival-4. Cardiovasc Drugs Ther. 1997;11(3):485-91. 
133. Ghafoorunissa. Requirements of dietary fats to meet nutritional needs and prevent the risk of atherosclerosis - an Indian perspective. Indian J Med Res. 1998; 108:191-202.

134. Azubuike NC, Okwuosa CN, Maduakor UC, Onwukwe OS, Onyemelukwe AO, Ogu CO, et al. Effects of methanolic extract of Brassica juncea seeds on biochemical parameters and histological integrity of the heart and liver of albino rats. Int J Morphol. 2019;37(1):237-40.

135. Willatgamuva SA, Platel K, Sarawathi G, Srinivasan K. Antidiabetic influence of dietary cumin seeds (Cuminum cyminum) in streptozotocin induced diabetic rats. Nutr Res. 1998;18(1):31-42.

136. Dhandapani S, Subramanian VR, Rajagopal S, Namasivayam N. Hypolipidemic effect of Cuminum cyminum $L$. on alloxan-induced diabetic rats. Pharmacol Res. 2002;46(3):251-5.

137. Patil SB, Takalikar SS, Joglekar MM, Haldavnekar VS, Arvindekar AU. Insulinotropic and $\beta$-cell protective action of cuminaldehyde, cuminol and an inhibitor isolated from Cuminum cyminum in streptozotocin-induced diabetic rats. $\mathrm{Br} J$ Nutr. 2013;110(8):1434-43.

138. Snehlata HS, Payal DR. Fenugreek (Trigonella foenum graecum L.): An overview. Int J Curr Pharm Rev Res. 2012;2(4):169-87.

139. Roberts KT. The potential of fenugreek (Trigonella foenum-graecum) as a functional food and nutraceutical and its effects on glycemia and lipidemia. Med Food. 2011;14(12):1485-9.

140. Fuller S, Stephens JM. Diosgenin, 4-hydroxyisoleucine and fiber from fenugreek: Mechanisms of actions and potential effects on metabolic syndrome. Adv Nutr. 2015;6(2):189-97.

141. Subramanian SP Prasath GS. Antidiabetic and antidyslipidemic nature of trigonelline, a major alkaloid of fenugreek seeds studied in high-fat-fed and low-dose streptozotocin-induced experimental diabetic rats. Biomed Prev Nutr. 2014;4(4):475-80

142. Salama RH. Hypoglycemic effect of lipoic acid, carnitine and Nigella sativa in diabetic rat model. Int J Health Sci. 2011;5(2):126-34.

143. Abdelmeguid NE, Fakhoury R, Kamal SM, Al Wafai RJ. Effects of Nigella sativa and thymoquinone on biochemical and subcellular changes in pancreatic $\beta$-cells of streptozotocin-induced diabetic rats. J Diabetes. 2010;2(4):256-66.

144. Kanter M, Akpolat M, Aktas C. Protective effects of the volatile oil of Nigella sativa seeds on beta-cell damage in streptozotocin-induced diabetic rats: A light and electron microscopic study. J Mol Histol. 2009;40(5-6):379-85.

145. Altan MF, Kanter M, Donmez S, Kartal ME, Buyukbas S. Combination therapy of Nigella sativa and human parathyroid hormone on bone mass, biomechanical behavior and structure in streptozotocin-induced diabetic rats. Acta Histochem. 2007;109(4):304-14

146. Najmi A, Haque SF, Naseeruddin M, Khan RA. Effect of Nigella sativa oil on various clinical and biochemical parameters of metabolic syndrome. Int J Diabetes Dev Ctries 2008;16:85-7.

147. Anitha T, Balakumar C, llango KB, Benedict Jose C, Vetrivel D. Antidiabetic activity of the aqueous extracts of Foeniculum vulgare on streptozotocininduced diabetic rats. Int J Adv Pharm Biol Chem. 2014;8:487-94.

148. Godavari A, Amutha K, Moorthi NM. In vitro hypoglycaemic effect of Foeniculum vulgare Mill. seeds on the carbohydrate hydrolyzing enzymes, $\alpha$-amylase and $\alpha$-glucosidase. Int J Pharm Sci Res. 2018;9(10):4441-5.

149. Thirumalai T, Therasa SV, Elumalai EK, David E. Hypoglycemic effect of Brassica juncea (seeds) on streptozotocin induced diabetic male albino rat. Asian Pac J Trop Biomed. 2011;1(4):323-5

150. Yadav SP, Vats V, Ammini AC, Grover JK. Brassica juncea (Rai) significantly prevented the development of insulin resistance in rats fed fructose-enriched diet. J Ethnopharmacol. 2004;93(1):113-6.

151. Grover JK, Yadav S, Vats V. Hypoglycemic and antihyperglycemic effect of Brassica juncea diet and their effect on hepatic glycogen content and the key enzymes of carbohydrate metabolism. Mol Cell Biochem. 2002;241(1-2): 95-101.

152. Ozbek H, Ugras S, Dülger H, Bayram I, Tuncer I, Oztürk G, et al. Hepatoprotective effect of Foeniculum vulgare essential oil. Fitoterapia. 2003;74(3):317-9.

153. Mostafa DM, Abd El-Alim SH, Asfour MH, Al-Okbi SY, Mohamed DA, Hamed TE, et al. Transdermal fennel essential oil nanoemulsions with promising hepatic dysfunction healing effect: In vitro and in vivo study. Pharm Dev Technol. 2019;24(6):729-38

154. Ozbek H, Ugras S, Bayram I, Uygan I, Erdogan E, Ozturk A, et al. Hepatoprotective effect of Foeniculum vulgare essential oil: A carbon-tetrachloride induced liver fibrosis model in rats. Scand J Lab Anim Sci. 2004;31(1):9-17.

155. Yildiz F, Coban S, Terzi A, Ates M, Aksoy N, Cakir H, et al. Nigella sativa relieves the deleterious effects of ischemia reperfusion injury on liver. World J Gastroenterol. 2008;14(33):5204-9.

156. Tuorkey MJ. Therapeutic potential of Nigella sativa oil against cyclophosphamide-induced DNA damage and hepatotoxicity. Nutr Cancer. 2017;69(3): 498-504.

157. Zafeer MF, Waseem M, Chaudhary S, Parvez S. Cadmium-induced hepatotoxicity and its abrogation by thymoquinone. J Biochem Mol Toxicol 2012;26(5): 199-205.

158. Nishadh A, Selvi V, Mahalakshmi R. Hepatoprotective effect of Vernonia cinerea and cumin seeds on carbon tetrachloride induced hepatic oxidative stress. Int J Drug Dev Res. 2013;5:215-20.

159. Mushtaq A, Ahmad M, Jabeen Q, Saqib A, Wajid M, Akram AA. Hepatoprotective investigations of Cuminum cyminum dried seeds in nimesulide intoxicated albino rats by phytochemical and biochemicalmethods. Int J Pharm Pharm Sci. 2014:6(4):506-10.

160. Abbas N, Alyousef L, Agabien EM, Ahmed ES, Ahmed AS, Begum A. Comparative study of hepatoprotective effect produced by Cuminum cyminum and Nigella sativa against cisplatin-induced hepatotoxicity; with histopathological studies. Int J Pharm Sci Res. 2018;9(1):393-401.

161. Sheweita SA, El-Hosseiny LS, Nashashibi MA. Protective effects of essential oils as natural antioxidants against hepatotoxicity induced by cyclophosphamide in mice. PLoS One. 2016;11(11):e0165667.

162. Parikh H, Pandita N, Khanna A. Phytoextract of Indian mustard seeds acts by suppressing the generation of ROS against acetaminophen-induced hepatotoxicity in HepG2 cells. Pharm Biol. 2015;53(7):975-84.

163. Walia A, Malan R, Saini S, Saini V, Gupta S. Hepatoprotective effects from the leaf extracts of Brassica juncea in $\mathrm{CCl} 4$ induced rat model. Pharm Sin. $2011 ; 2(4): 274-85$

164. Das S. Hepatoprotective activity of methanol extract of fenugreek seeds on rats. Int J Pharm Sci Res. 2014;5(4):1506-13.

165. Reddy RR, Srinivasan K. Hepatoprotective and antioxidant effect of fenugreek (Trigonella foenum-graecum) seeds in mice under lithogenic condition. J Food Biochem. 2011;35(6):1619-26.

166. Kandhare AD, Bodhankar SL, Mohan V, Thakurdesai PA. Glycosides based standardized fenugreek seed extract ameliorates bleomycin-induced liver fibrosis in rats via modulation of endogenous enzymes. J Pharm Bioallied Sci. 2017;9(3):185-94.

167. Tharaheswari M, Jayachandra RN, Kumar R, Varshney KC, Kannan M, Sudha RS et al. Trigonelline and diosgenin attenuate ER stress, oxidative stress-mediated damage in pancreas and enhance adipose tissue PPARy activity in type 2 diabetic rats. Mol Cell Biochem. 2014;396(1-2):161-74.

168. Birdane FM, Cemek M, Birdane YO, Gülcin I, Büyükokuroglu ME. Beneficial effects of Foeniculum vulgare on ethanol-induced acute gastric mucosal injury in rats. World J Gastroenterol. 2007;13(4):607-11.

169. Oliveira FA, Andrade LN, DeSousa EB, DeSousa DP. Anti-ulcer activity of essential oil constituents. Molecules. 2014;19(5):5717-47.

170. Antonisamy P, Arasu MV, Dhanasekaran M, Choi KC, Aravinthan A, Kim NS et al. Protective effects of trigonelline against indomethacin-induced gastric ulcer in rats and potential underlying mechanisms. Food Funct. 2016;7(1):398-408

171. Platel K, Srinivasan K. Influence of dietary spices and their active principles on pancreatic digestive enzymes in albino rats. Nahrung. 2000;44(1):42-6.

172. Magdy MA, Hanan el-A, Nabila el-M. Thymoquinone: Novel gastroprotective mechanisms. Eur J Pharmacol. 2012;697(1-3):126-31.

173. Al Mofleh IA, Alhaider AA, Mossa JS, Al-Sohaibani MO, Al-Yahya MA Rafatullah S, et al. Gastroprotective effect of an aqueous suspension of black cumin Nigella sativa on necrotizing agents-induced gastric injury in experimental animals. Saudi J Gastroenterol. 2008;14(3):128-34.

174. Lei X, Liu M, Yang Z, Ji M, Guo X, Dong W. Thymoquinone prevents and ameliorates dextran sulfate sodium-induced colitis in mice. Dig Dis Sci. 2012;57(9):2296-303

175. Boskabady $\mathrm{MH}$, Khatami A, Nazari A. Possible mechanism(s) for relaxant effects of Foeniculum vulgare on guinea pig tracheal chains. Pharmazie. 2004;59(7):561-4

176. Albert-Puleo M. Fennel and anise as estrogenic agents. J Ethnopharmacol. 1980;2(4):337-44

177. Wienkötter N, Höpner D, Schütte U, Bauer K, Begrow F, El-Dakhakhny M, et al. The effect of nigellone and thymoquinone on inhibiting trachea contraction and mucociliary clearance. Planta Med. 2008;74(02):105-8

178. Hossein BM, Nasim V, Sediqa A. The protective effect of Nigella sativa on lung injury of sulfur mustard-exposed Guinea pigs. Exp Lung Res. 2008;34(4): 183-94.

179. Kanter M. Effects of Nigella sativa seed extract on ameliorating lung tissue damage in rats after experimental pulmonary aspirations. Acta Histochem. 2009; $111(5): 393-403$

180. Boskabady MH, Mohsenpoor N, Takaloo L. Antiasthmatic effect of Nigella sativa in airways of asthmatic patients. Phytomedicine. 2010;17(10):707-13.

181. Pejman L, Omrani H, Mirzamohammadi Z, Keyhanmanesh R. Thymoquinone, the main constituent of Nigella sativa, affects adenosine receptors in asthmatic guinea pigs. Iran J Basic Med Sci. 2014;17(2):1012-9.

182. Boskabady MH, Kiani S, Azizi H, Khatami T. Antitussive effect of Cuminum cyminum Linn.in guinea pigs. Natl Prod Radiance. 2006;5(4):266-9.

183. Emtiazy M, Oveidzadeh L, Habibi M, Molaeipour L, Talei D, Jafari Z, et al Investigating the effectiveness of the Trigonella foenum-graecum L. (fenugreek) seeds in mild asthma: A randomized controlled trial. Allergy Asthma Clin Immunol. 2018;14(1):19.

184. Gao M, Chen L, Yu H, Sun Q, Kou J, Yu B. Diosgenin down-regulates NF-kB p65/p50 and p38MAPK pathways and attenuates acute lung injury induced by 
lipopolysaccharide in mice. Int Immunopharmacol. 2013;15(2):240-5.

185. Atrooz OM. The effects of Cuminum cyminum $L$ and Carum carvi $L$ seed extracts on human erythrocyte hemolysis. Int J Biol. 2013;5(2):57-63.

186. Morshedi D, Kesejini TS, Aliakbari F, Karami-Osboo R, Shakibaei M, Marvian AT, et al. Identification and characterization of a compound from Cuminum cyminum essential oil with antifibrilation and cytotoxic effect. Res Pharm Sci. 2014;9(6):431-43
187. Javidnia K, Dastgheib L, Mohammadi SS, Nasiri A. Antihirsutism activity of fennel (fruits of Foeniculum vulgare) extract. A double-blind placebo controlled study. Phytomedicine. 2003;10(6-7):455-8.

188. Malini T, Vanithakumari G, Megala N, Anusya S, Devi K, Elango V. Effect of Foeniculum vulgare mill. Seed extract on the genital organs of male and female rats. Indian J Physiol Pharmacol. 1985;29:21-6.

189. Gökçe A, Oktar S, Koc A, Yonden Z. Protective effects of thymoquinone against methotrexate-induced testicular injury. Hum Exp Toxicol. 2011;30(8):897-903.

Cite this article: Sarkar D. A Review of the Seeds Comprising Panch phoron, a Spice used in Indian Cuisine. Int. J. Pharm. Investigation. 2019;9(2):25-35. 